\title{
Vegetation and climate changes around the Lama Lake, Taymyr Peninsula, Russia during the Late Pleistocene and Holocene
}

\author{
A.A. Andreev ${ }^{\mathrm{a}, *}$, P.E. Tarasov ${ }^{\mathrm{b}}$, V.A. Klimanov ${ }^{\mathrm{c}}$, M. Melles ${ }^{\mathrm{d}}$, O.M. Lisitsyna ${ }^{\mathrm{e}}$, \\ H.-W. Hubberten ${ }^{\mathrm{a}}$ \\ a Alfred Wegener Institute for Polar- and Marine Research, Forschungsstelle Potsdam, Telegrafenberg A43, Potsdam D-14473, Germany \\ ${ }^{\mathrm{b}}$ Department of Geography, Moscow State University, Vorobievy Gory, Moscow 119899, Russia \\ ${ }^{\mathrm{c}}$ Institute of Geography, RAS, Staromonetny 29, Moscow 109017, Russia \\ ${ }^{\mathrm{d}}$ Faculty for Physics and Earth Sciences, Institute for Geophysics and Geology, Leipzig University, Talstrasse 35, Leipzig D-04103, Germany \\ ${ }^{\mathrm{e}}$ Department of Geology, Moscow State University, Vorobievy Gory, Moscow 119899, Russia
}

Received 4 January 2004; accepted 4 January 2004

\begin{abstract}
A continuous lacustrine sequence from the western part of Lama Lake $\left(69^{\circ} 32^{\prime} \mathrm{N}, 90^{\circ} 12^{\prime} \mathrm{E}\right)$, complemented by a peat sequence from the lake catchment provides the first detailed environmental reconstruction for the Late Glacial and Holocene on the Taymyr Peninsula. Scarce steppe-like communities with Artemisia, Poaceae, and Cyperaceae dominated during the Late Glacial. Tundra-like communities with Betula nana, Dryas, and Salix grew on more mesic sites. There are distinct climatic signals, which may be correlated with the Bølling and Allerød warming and Middle and Younger Dryas cooling. The Late Glacial/Preboreal transition, at about $10,000{ }^{14} \mathrm{C}$ yr BP, was characterized by changes from predominantly open herb communities to shrub tundra ones. Larch forest might have been established as early as $9700-9600{ }^{14} \mathrm{C}$ yr BP, whilst shrub alder came to the area ca $9500-9400{ }^{14} \mathrm{C}$ yr BP, and spruce did not reach area before ca $9200{ }^{14} \mathrm{C}$ yr BP. Spruce-larch forests with shrub alder and tree birch dominated the vegetation around the Lama Lake from ca $9000{ }^{14} \mathrm{C}$ yr BP. Dwarf birch communities were also broadly distributed. The role of spruce in the forest gradually decreased after $4500{ }^{14} \mathrm{C}$ yr BP. The vegetation cover in the Lama Lake area became similar to the modern larch-spruce forest ca 2500 ${ }^{14} \mathrm{C}$ yr BP. A pollen-based biome reconstruction supports a quantitative interpretation of the pollen spectra. Climate reconstructions obtained with information-statistical and plan-functional-type methods show very similar trends in reconstructed July temperature since ca $12,300{ }^{14} \mathrm{C}$ yr BP, while precipitation anomalies are less coherent, especially during the Late Glacial-Holocene transition. (C) 2004 Elsevier Ltd and INQUA. All rights reserved.
\end{abstract}

\section{Introduction}

Arctic regions are highly sensitive to changes in temperature and precipitation, and their Late Quaternary environmental history is very important for understanding present and past climate trends. The Taymyr Peninsula (Fig. 1), in particularly, its western part, situated in a transition zone between the more Atlanticinfluenced West Siberia and the more continental East Siberia, is a region sensitive to climate fluctuations. Thus, this area is probably one of the most promising regions for the reconstruction of the Late Quaternary

\footnotetext{
*Corresponding author.

E-mail addresses: aandreev@awi-potsdam.de (A.A. Andreev), paveltarasov@hotmail.com (P.E. Tarasov), paleo@glasnet.ru (V.A. Klimanov), melles@rz.uni-leipzig.de (M. Melles), olis@postman.ru (O.M. Lisitsyna), hubbert@awi-potsdam.de (H.-W. Hubberten).
}

environment in dependence on changes in global and regional climate and the atmospheric circulation.

The Late Quaternary history of the Taymyr Peninsula has been the subject of speculative debate, mostly due to the lack of empirical data. Grosswald (1998) proposed that a huge Ice Sheet covered the area during the Late Weichselian. Although field data indicate that the glaciation was restricted to mountain areas on the Taymyr Peninsula (e.g. Isaeva, 1984; Faustova and Velichko, 1992; Möller et al., 1999), a number of climate models (e.g. Kutzbach et al., 1993; Joussaume, 1999) have assumed that northern Siberian plains were glaciated during the Last Glacial Maximum (LGM: ca $18,000{ }^{14} \mathrm{C}$ yr BP). As a result, the simulated LGM climate and circulation pattern of the Siberian Arctic are unrealistic (Tarasov et al., 1999b; Felzer, 2001).

A multidisciplinary German-Russian research project "Taymyr" was established in 1993 in order to improve 


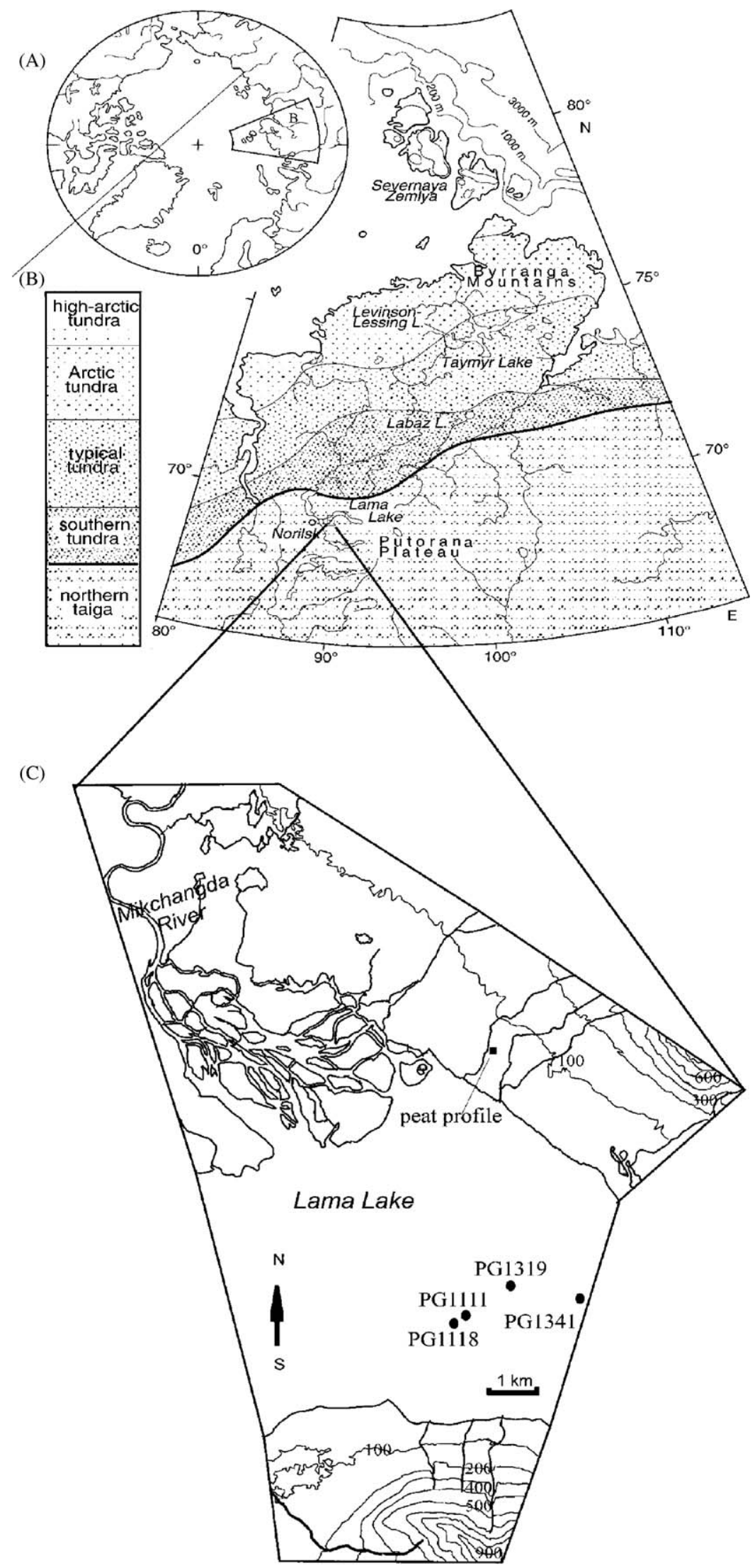

Fig. 1. (A) Maps of the Arctic, (B) the Taymyr-Severnaya Zemlya region, and (C) the western part of Lama Lake area with locations of the investigated sites. 
the knowledge about the Late Quaternary of the region (Melles et al., 1996). Pollen studies of lacustrine and terrestrial sequences were carried out at a number of sites along a transect from the vicinity of Norilsk to the October Revolution Island on Severnaya Zemlya (Hahne and Melles, 1997, 1999; Kienel et al., 1999; Siegert et al., 1999; Andreev et al., 2002).

The important information about long-term vegetation and climate changes on the Taymyr Peninsula comes from the continuous sediment core from Lama Lake (PG1111). Hahne and Melles (1997, 1999) provided an initial reconstruction of the vegetation and climate history since the Late Glacial from this core. High-resolution diatom, sedimentological, geochemical and rock magnetic analyses were also performed (Kienel, 1999; Hagedorn et al., 1999; Harwart et al., 1999; Nowaczyk et al., 2000). However, the value of these comprehensive multi-proxy investigations was lowered by absence of any reliable radiocarbon dates.

This paper presents qualitative and quantitative reconstructions of vegetation and climate in the Lama Lake area since ca $18,000{ }^{14} \mathrm{C}$ yr BP, based on the new interpretation of a recently completed pollen record from the core PG1111 and a nearby situated peat sequence. The chronology is established from recently obtained AMS ${ }^{14} \mathrm{C}$ dates and correlation to regional pollen records (Kul'tina et al., 1974; Nikol'skaya, 1980, 1982; Belorusova et al., 1987; Clayden et al., 1997; Andreev and Klimanov, 2000; Andreev et al., 2002).

The so-called information-statistical (IS) method (Klimanov, 1976, 1984) has been used to reconstruct Late Glacial and Holocene climate at dozens of sites across the former USSR (e.g. Frenzel et al., 1992; Velichko et al., 1997). The recently developed plantfunctional-type (PFT) method (Peyron et al., 1998) was successfully used to reconstruct LGM and mid-Holocene climates in northern Eurasia (Tarasov et al., 1999a, b). However, the results of climate reconstructions performed by the IS and PFT methods have not yet been directly compared. This is done for the first time with the pollen record from Lama Lake, discussed here. Moreover, this is the first time that the PFT method is used to reconstruct climate from the whole pollen sequence.

\section{Study area}

\subsection{Geology and geography}

Lama Lake is located at an altitude of $53 \mathrm{~m}$ a.s.l. in an east-west extending valley at the western margin of the Putorana Plateau (Fig. 1). The lake covers an area of $466 \mathrm{~km}^{2}$ and has a maximal length of $82 \mathrm{~km}$ and width of $13 \mathrm{~km}$ with a maximum depth of $254 \mathrm{~m}$. The mountains surrounding Lama Lake have steep slopes and reach altitudes of up to $1200 \mathrm{~m}$. The geological structure of the plateau is characterized by late Paleozoic to early Mesozoic continental basalt overlying Cambrian to Upper Permian marine carbonates, evaporites and continental sediments of the Tunguska Syncline (Galaziy and Parmuzin, 1981).

Tectonic movements, sediment erosion by glaciers and rivers, and temporary damming by moraines have formed the lake basin (Demidyuk and Kondrat'eva, 1989). There are two lake terraces, consisting of sandy, silty, and clayey deposits: the so-called Arylakhskaya (ca. $60 \mathrm{~m}$ high) and Ayaklinskaya (ca. $82 \mathrm{~m}$ high) lake terraces (Galaziy and Parmuzin, 1981). The terraces are partly covered by peatlands. Freezing of the peat deposits has formed numerous pingos, one of which on the surface of the second (Ayaklinskaya) lake terrace was sampled for this study.

The permafrost in the region is up to $700 \mathrm{~m}$ thick (Galaziy and Parmuzin, 1981). Hydrothermal activity following the uplift of the Putorana Plateau forms an exceptionally warm and wet microclimate in the Lama Lake catchment, leading to a lower thickness of permafrost (up to $100 \mathrm{~m}$ ) around the lake.

The area is characterized by a continental climate with long, severe winters, and short summers. The modern temperatures are about $10-14^{\circ} \mathrm{C}$ in July, -32 to $-34^{\circ} \mathrm{C}$ in January. Annual precipitation ranges from about 300 $400 \mathrm{~mm}$ at low elevations to about $600-800 \mathrm{~mm}$ on the western slopes of the Putorana Plateau (Atlas Arktiki, 1985). The frost-free period is ca. 35 days.

The vegetation cover varies in dependence on altitude. Dense taiga with spruce (Picea obovata), larch (Larix czekanovskii, rarer L. sibirica), and birch (Betula pubescens) grows up to $200-400 \mathrm{~m}$ a.s.1. (Galaziy and Parmuzin, 1981). Shrubs, including dwarf birch (Betula nana), shrub alder (Alnus fruticosa), juniper (Juniperus communis), and willow (Salix) are also typical in the vegetation. Only larches form open forest near tree line boundary. Where larch forest disappears, it is replaced by herb and shrub dominated tundra. Dwarf shrubs include Betula nana, Vaccinium vitis-idea, V. uliginosum, Empetrum hermaphroditum. Juniper (Juniperus sibirica) grows on rock placers. Carex ssp. and Eriophorum vaginatum characterize wetter sites. Typical steppe species (Thymus reverdattoanus, Dracocephalon nutans, Festuca altaica) have also been recorded on south-facing slopes. On the high elevation slopes mountain and rock debris tundra vegetation with Dryas punctata, Potentila nivalis, Salix polaris is widespread.

\section{Methods}

\subsection{Sampling, radiocarbon dating and pollen analysis}

The investigated PG1111 core was collected in the western part of Lama Lake $\left(69^{\circ} 32^{\prime} \mathrm{N}, 90^{\circ} 12^{\prime} \mathrm{E}\right)$ from a 
water depth of $52.2 \mathrm{~m}$, ca. $4.5 \mathrm{~km}$ from the Mikchangda River delta on the northern shore of lake (Fig. 1). Coring was carried out from a floating platform in the summer of 1993. A gravity corer was used to recover the uppermost sediments, while the lower sediments were recovered with a piston corer (Melles et al., 1994).

The peat profile is situated at $77 \mathrm{~m}$ a.s.1., ca. $0.8 \mathrm{~km}$ from the northern shore of Lama Lake and $1.4 \mathrm{~km}$ from the Mikchangda River (Fig. 1). Samples were collected from the cleaned section in $20-30 \mathrm{~cm}$ interval during field work by the Geology Department of Moscow State University in 1997.

Different types of organic matter (chemically enriched pollen, humic acids, total organic carbon, manually selected pollen, and microfossils) were used for ${ }^{14} \mathrm{C}$ dating by AMS.

The PG1111 core was sampled in $10 \mathrm{~cm}$ interval for pollen analysis in the laboratory. Pollen samples were prepared using standard techniques (Faegri and Iversen, 1989). For the samples below $760 \mathrm{~cm}$, only $100-150$ pollen grains were counted due to very low pollen concentrations. For the upper part of the core 400-500 pollen grains were counted, with spores tallied in addition. The frequency of the pollen taxa is calculated based upon the sum of terrestrial pollen taxa. Calculation of spore percentages was based upon the sum of pollen and spores. The relative abundances of re-deposited taxa are based upon a sum of pollen and re-deposited taxa, and the percentage of algae - upon the sum of pollen and algae (Berglund and RalskaJasiewiczowa, 1986).

\subsection{Biome reconstruction method}

The biome reconstruction method (Prentice et al., 1996) was used for the quantitative interpretation of the vegetation history. The method attributes pollen taxa to broad classes of plants (plant functional types, PFT), and then to main vegetation types (biomes). An assignment of pollen taxa from the northern Eurasia to PFTs and biomes has been presented (Tarasov et al., 1998, 1999b). Table 1 summarizes their results in a way suitable for the calculation of Central Siberia biome scores. Relative abundances of pollen taxa have been calculated in the same way as for the pollen diagrams. The biome affinity scores have been calculated using the PPPBASE software (Guiot and Goeury, 1996) with the following equation (Prentice et al., 1996): $A_{i k}=$ $\sum_{j} \delta_{i j} \sqrt{\left\{\max \left[0,\left(p_{j k}-\theta_{j}\right)\right]\right\}}$, where $A_{i k}$ is the affinity of pollen sample $k$ for biome $i$; summation is over all taxa $j ; \delta_{i j}$ is the entry in the biome versus taxon matrix for biome $i$ and taxon $j ; p_{j k}$ are the pollen percentages, and $\theta_{j}$ is an universal threshold pollen percentage of $0.5 \%$.

The biome with the highest score or, when several biomes had the same score, the one defined by a smaller number of taxa/PFTs, was then assigned to the given pollen spectrum, allowing the reconstruction of the temporal changes in the biome distribution around Lama Lake. Furthermore, the known bioclimatic limits of modern plant growth used in the BIOME1 model (Prentice et al., 1992) provide another way to interpret reconstructed changes in terms of climate.

\subsection{Climate reconstruction methods}

The IS method is one of the two methods chosen to reconstruct climate from the Lama fossil pollen spectra. The method establishes transfer functions between the surface pollen spectra and modern climate at the sampling sites. Percentages of arboreal and nonarboreal pollen and spore and abundances of most common tree and shrub taxa are taken in to consideration. More than 800 recent pollen spectra from 220 sites across the former USSR were used to work out the technique (Klimanov, 1976, 1984). Modern climate variables were taken from the Klimaticheskiy Atlas SSSR (1960). Climatic variables used in the reconstructions comprise mean annual $\left(T_{\mathrm{yr}}\right)$, January $\left(T_{\mathrm{I}}\right)$, and July $\left(T_{\mathrm{VII}}\right)$ temperatures and mean annual precipitation $(P)$. A statistical treatment of the modern pollen and climate data resulted in the preparation of tables, revealed the correlation between pollen data and the climatic variables (Klimanov, 1976, 1984).

Table 1

Assignment of pollen taxa to Central Siberia biomes, as used for the calculation of biome scores, according to Tarasov et al. (1998, 1999b)

\begin{tabular}{ll}
\hline Biome & Pollen taxa included \\
\hline Tundra & $\begin{array}{l}\text { Alnus fruticosa-type, Betula nana-type, Draba, Dryas, Gentianaceae, Saxifragaceae, Ericales, Cyperaceae, Poaceae, Rubus } \\
\text { chamaemorus, Betula undif., Alnus undif., Salix }\end{array}$ \\
Cold deciduous & Betula sect. Albae, Larix, Alnus glutinosa-type, A. incana-type, Populus, Pinus subgenus Haploxylon, Juniperus, \\
forest & Pinus subgenus Diploxylon, Rubus chamaemorus, Betula undif., Alnus undif., Salix \\
Taiga & Abies, Picea, Betula sect. Albae, Larix, Alnus glutinosa-type, A. incana-type, Populus, Pinus subgenus Haploxylon, \\
Steppe & Juniperus, Pinus subgenus Diploxylon, Rubus chamaemorus, Betula undif., Ericales, Alnus undif., Salix \\
& Allium, Apiaceae, Armeria, Asteraceae subf. Asteroideae, Asteraceae subf. Cichorioideae, Boraginaceae, Brassicaceae, \\
& Crassulaceae, Campanulaceae, Cannabis, Caryophyllaceae, Centaurea, Dipsacaceae, Echium, Euphorbiaceae, Fabaceae, \\
& Hippophae, Polygonaceae, Filipendula, Galium, Helianthemum, Lamiaceae, Plantago undif., Plumbaginaceae, \\
& Ranunculaceae, Rosaceae, Rubiaceae, Scrophulariaceae, Artemisia, Chenopodiaceae, Poaceae
\end{tabular}


The PFT method (Peyron et al., 1998) is based on the biomization concept of Prentice et al. (1996) already used for the reconstruction of vegetation in northern Eurasia (Tarasov et al., 1998, 2000). The method uses PFT scores instead of the pollen taxa abundances, following the hypothesis (Prentice et al., 1992) that groups of taxa have a better-defined response to climate than individual taxa, whose responses to climate change may be obscured by competition and migration processes.

A set of 1245 surface pollen spectra, covering northern Eurasia and western North America (Tarasov et al., $1999 \mathrm{a}, \mathrm{b}$ ) has used to establish the relationships between the numerical PFT scores and six modern climate variables at the sampling sites. Assignments of pollen taxa, used for the calculation of PFT scores are present in Table 2. Some taxa can be present in more than one PFT, creating a technical problem for the calculation of the PFT scores. To overcome this problem, Peyron et al. (1998) have suggested the so-called virtual PFT, defined as a group of the PFTs to which an ambiguous taxon belongs. Virtual PFTs are shown in the code column of Table 2 with a slash between the basic PFTs. The PFT scores have been calculated in the same way as the biome scores. The modern climate at sampling sites was calculated using the PPPBASE software (Guiot and Goeury, 1996) and the climate database (Leemans and Cramer, 1991). An artificial neural network technique, included in the PPPBASE software, helps to calibrate PFT scores from the modern pollen spectra in terms of the analyzed climatic parameters (Tarasov et al., 1999a, b). The obtained transfer function was applied to the PFT scores calculated for the PG1111 core pollen spectra to reconstruct climate.

The reconstruction error by the IS method is $\pm 0.6^{\circ} \mathrm{C}$ for $T_{\mathrm{yr}}$ and $T_{\mathrm{VII}} ; \pm 1.0^{\circ} \mathrm{C}$ for $T_{\mathrm{I}}$ and $\pm 25 \mathrm{~mm}$ for $P_{\mathrm{yr}}$ (Klimanov, 1976, 1984). However, Peyron et al. (2000) shows that statistical methods applied to pollen often underestimate the error bars for the reconstructed variables. In contrast, the error bars obtained with the PFT method are often large. A comparison of climate variables inferred from surface pollen by the PFT method with actual climate demonstrates the sufficiently good correlation: 0.93 for $T_{\mathrm{VII}}$ and 0.7 for $P_{\mathrm{yr}}$ (Tarasov et al., 1999a). Error bars for the reconstructed LGM and mid-Holocene climate anomalies in northern Eurasia are different in terms of confidence level. For example, error bars of reconstructed $T_{\mathrm{VII}}$ anomalies vary between -1 and $+0.9^{\circ} \mathrm{C}$ at $75 \%$ level of confidence and between -2.5 and $+2.6^{\circ} \mathrm{C}$ at $95 \%$ of confidence levels (Tarasov et al., 1999a, b).

The IS method uses mainly arboreal pollen and thus is more applicable in forested areas and less in transitional (e.g. forest-tundra) ones. Reconstructions in the treeless areas and time intervals (e.g. LGM) are not very reliable. This statement was checked with the surface spectra from the northern taiga (Lama Lake), shrubby tundra (Labaz Lake) and typical tundra (Levinson-Lessing Lake). The IS method provides reliable $T_{\mathrm{VII}}$ and $P_{\mathrm{yr}}$ reconstruction in taiga, but reconstructed $T_{\mathrm{VII}}$ in tundra is much warmer than the actual values (Table 3 ). The PFT climate reconstructions (this method takes into account arboreal as well as nonarboreal pollen and thus is more appropriate in treeless

Table 2

Assignment of pollen taxa to basic and virtual PFT's, as used for the calculation of PFT scores in the records from Central Siberia, according to Tarasov et al. (1999a, b)

\begin{tabular}{lll}
\hline Basic PFT & Code & Pollen taxa included \\
\hline Steppe forb/shrub & $\mathrm{sf}$ & Allium, Apiaceae, Armeria, Asteraceae subf. Asteroideae, Asteraceae subf. Cichorioideae, \\
& & Boraginaceae, Brassicaceae, Crassulaceae, Campanulaceae, Caryophyllaceae, Cannabis-type, \\
& & Centaurea, Dipsacaceae, Echium, Euphorbiaceae, Fabaceae, Hippophae, Polygonaceae, \\
& & Filipendula, Galium, Helianthemum, Lamiaceae, Plantago undif., Plumbaginaceae, \\
& & Ranunculaceae, Rosaceae, Rubiaceae, Scrophulariaceae \\
Grass & $\mathrm{sf} / \mathrm{df}$ & Artemisia, Chenopodiaceae \\
Heath & $\mathrm{g}$ & Poaceae \\
Sedge & $\mathrm{h}$ & Ericales \\
Arctic-alpine dwarf shrub/herb & $\mathrm{s}$ & Cyperaceae \\
Arctic-boreal semi-shrub & $\mathrm{aa}$ & Alnus fruticosa-type, Betula nana-type, Draba, Dryas, Gentianaceae, Saxifragaceae \\
Boreal evergreen conifer & $\mathrm{ab}$ & Rubus chamaemorus \\
Boreal summergreen & $\mathrm{bec}$ & Picea \\
Cool-boreal conifer & $\mathrm{bs}$ & Betula sect. Albae, Larix \\
Eurythermic conifer & $\mathrm{cbc}$ & Pinus subgenus Haploxylon \\
& $\mathrm{ec}$ & Juniperus, Pinus subgenus Diploxylon \\
& $\mathrm{bec} / \mathrm{ctc}$ & Abies \\
& $\mathrm{aa} / \mathrm{bs}$ & Betula undif. \\
& $\mathrm{aa} / \mathrm{bs} / \mathrm{ts}$ & Alnus undif., Salix \\
& $\mathrm{bs} / \mathrm{ts}$ & Alnus glutinosa-type, A. incana-type, Populus
\end{tabular}

Virtual PFTs are shown in the code column with a slash between the basic PFTs. ctc is the code of cool-temperate conifer PFT, ts is the code for temperate summergreen PFT, and df is the code for desert forb PFT. 
Table 3

Modern $T_{\mathrm{VII}}$ and $P_{\mathrm{yr}}$ ranges derived from Klimaticheskiy Atlas SSSR (1960) and Atlas Arktiki (1985) and reconstructed from surface pollen data by the IS and the PFT methods at 3 locations on the Taymyr Peninsula

\begin{tabular}{|c|c|c|c|c|c|c|c|}
\hline \multirow[t]{2}{*}{ Location } & \multirow[t]{2}{*}{ Vegetation (Atlas Arktiki, 1985) } & \multicolumn{3}{|l|}{$T_{\mathrm{VII}}\left({ }^{\circ} \mathrm{C}\right)$} & \multicolumn{3}{|l|}{$P_{\mathrm{yr}}(\mathrm{mm})$} \\
\hline & & Modern data & IS & PFT & Modern data & IS & PFT \\
\hline Lama Lake $\left(69^{\circ} \mathrm{N}, 90^{\circ} \mathrm{E}\right)$ & Northern taiga & $10-14$ & $14-16$ & $13.5-15.5$ & $300-800$ & $400-500$ & $300-500$ \\
\hline Labaz Lake $\left(72^{\circ} \mathrm{N}, 99^{\circ} \mathrm{E}\right)$ & Southern tundra & $8-12$ & $10-14$ & $8.5-10.5$ & $300-400$ & $300-400$ & $300-500$ \\
\hline Levinson-Lessing Lake $\left(74^{\circ} \mathrm{N}, 98^{\circ} \mathrm{E}\right)$ & Typical tundra & $6-8$ & $10-14$ & $7-9$ & $250-350$ & $300-400$ & $200-400$ \\
\hline
\end{tabular}

areas) are in good agreement with the actual climate in all sites.

The BIOME1 vegetation model (Prentice et al., 1992) suggests that summer $T$ and moisture conditions are main factors, controlling transition between tundra, cold deciduous forest, taiga and cool steppe. As an objective reconstruction of the climate and comparison of the IS and PFT methods are among the main goals of this study, we have chosen only $T_{\mathrm{VII}}$ and $P_{\mathrm{yr}}$ reconstructions to present in the paper.

\section{Results}

\subsection{PG1111 core}

The lowermost $1112-735 \mathrm{~cm}$ of the core consists of $<1-10 \mathrm{~mm}$ thick laminated silt and clay, characterized by olive-brown colors (Fig. 2). The upper $735-600 \mathrm{~cm}$ is characterized by regular black and dark-gray laminae with thickness $<1 \mathrm{~mm}$ and change from olivebrown silty clay to gray-black clayey silt. The upper $600-505 \mathrm{~cm}$ consist of clayey silt with a thicker $(1-2 \mathrm{~cm})$ black layering than below. The uppermost $505-0 \mathrm{~cm}$ is composed of $0.01-2 \mathrm{~cm}$ thick irregularly layered black layers. For the detailed lithostratigraphy see Harwart et al. (1999).

The pollen diagram is zoned by visual inspection (Fig. 2). Pollen zone I (PZ-I, $1110-760 \mathrm{~cm}$ ) has very low pollen concentration. The spectra are dominated by Artemisia, Poaceae, and Cyperaceae pollen. Pollen of Salix, Betula sect. Nanae and some herbs taxa like Saxifraga, Caryophyllaceae also occur in the spectra. PZ-II $(760-700 \mathrm{~cm})$ is notable for dramatic increase of Betula sect. Nanae pollen contents, while Poaceae and Artemisia ones are reduced. PZ-III $(700-650 \mathrm{~cm})$ is characterized by a decrease in Betula percentages, while Cyperaceae percentages are significantly increased. A peak of Botryococcus also occurs in this zone. PZ-IV $(650-550 \mathrm{~cm})$ is notable for an increase in Betula sect. Nanae, Larix and Salix pollen, Polypodiaceae, Sphagnum, Equisetum spores and a decrease in Cyperaceae, Artemisia, Saxifraga, Caryophyllaceae, Thalictrum and some other herbs. In the upper part of the zone Alnus fruticosa pollen and Lycopodium clavatum spores percentages increase. PZ-V $(550-505 \mathrm{~cm})$ is characterized by the increase of Picea obovata and Betula sect. Albae pollen percentages, while B. sect. Nanae, Larix and Salix pollen percentages decrease. Pollen concentration is the highest in this zone. PZ-VI $(505-205 \mathrm{~cm})$ is noticeable for a high content of Picea obovata and Betula sect. Albae pollen. Lycopodium spores content also increase in this zone. PZ-VII $(205-100 \mathrm{~cm})$ is characterized by a gradual decrease of Picea obovata and Betula sect. Albae percentages, while Larix, Salix, Cyperaceae, Lycopodium, Selaginella, and Sphagnum contents increase. PZ-VIII $(100-0 \mathrm{~cm})$ is notable for slight increase in Pinus, Artemisia, and Cyperaceae contents. Lycopodium and Selaginella contents reach the maximum in this zone. Betula sect. Albae percentages increase in the upper part of the zone, while Larix and Picea obovata have small peaks in the lower part.

Thirty samples from the core were ${ }^{14} \mathrm{C}$ dated by AMS (Table 4). Different fractions of organic matter (chemically enriched pollen, humic acids, total organic carbon, manually selected pollen and microfossils) were dated. Unfortunately, these fractions gave widely diverging ages (Table 4), resulting from low organic matter and high content of coal particles. Manually selected microfossil samples provide more reliable data, but they are rare due to the generally low content in organic matter. Probably due to contamination problems, some of these dates also provide a rather wide scatter, making the creation of an age depth model difficult. A relatively good data set, corresponding well with radiocarbon dated pollen sequences from the region (Table 5), was obtained only for the $10,000-8000{ }^{14} \mathrm{C}$ yr BP interval. An age model based on macrofossil dates and correlated pollen stratigraphy from relatively well-dated sequences (e.g. Clayden et al., 1997; Andreev and Klimanov, 2000; Andreev et al., 2002) is presented in Fig. 3. A set of ${ }^{210} \mathrm{~Pb}$ ages (Hagedorn et al., 1999) and ${ }^{14} \mathrm{C}$ dates from the adjacent PG1319 and PG1341 cores (Table 4) confirm our age interpolation for the upper part of the core. An extrapolation, based on reliable dates and regional pollen stratigraphies shows that the sediment base could be $18,000{ }^{14} \mathrm{C}$ yr BP old (Fig. 3). However, it is well known that during Late Glacial times 


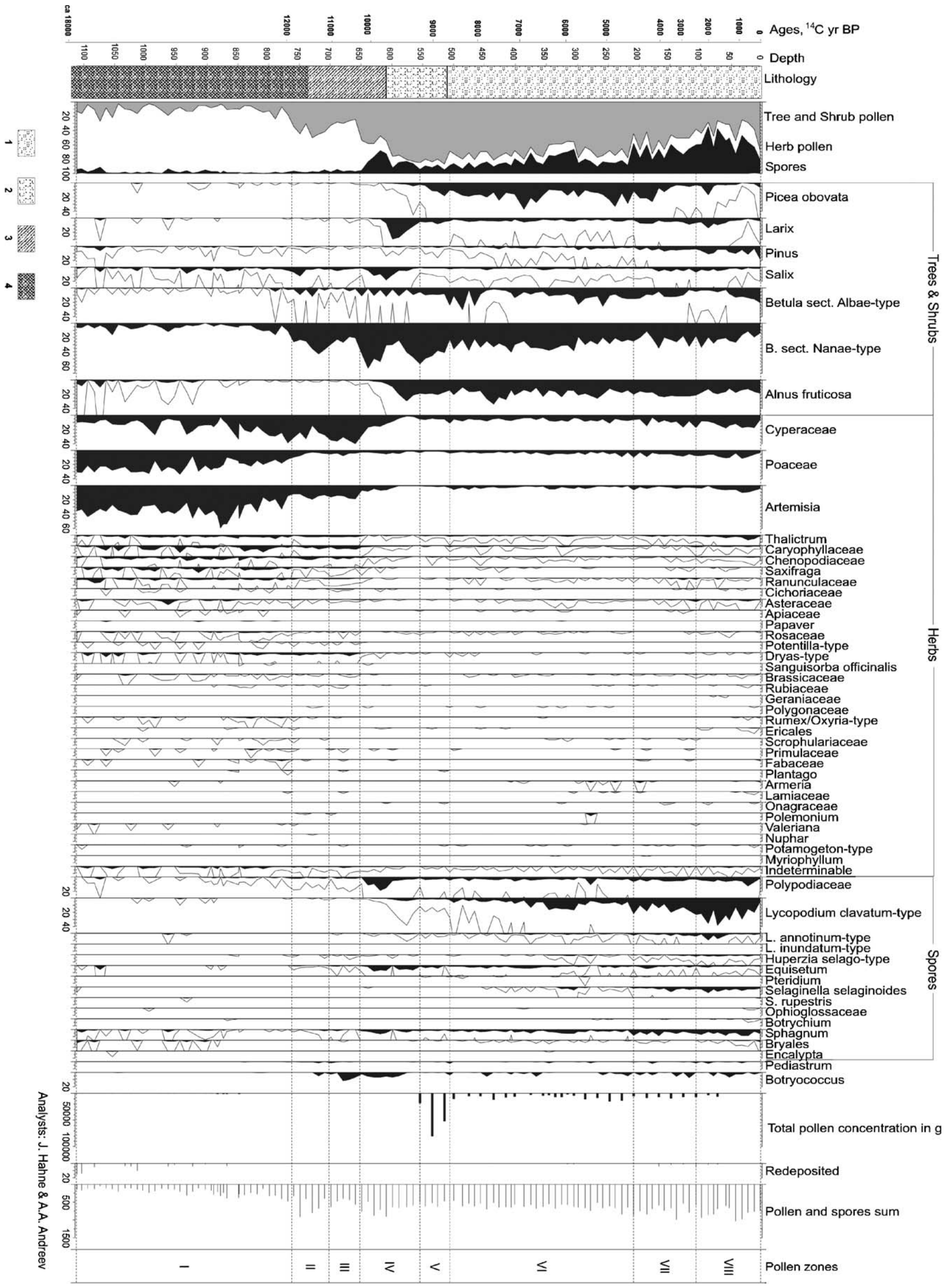

Fig. 2. Percentage pollen and spore diagram of the PG1111 core $\left(72^{\circ} 22^{\prime} 6^{\prime \prime} \mathrm{N}, 99^{\circ} 42^{\prime} 2^{\prime \prime} \mathrm{E}\right)$. (1) $0.01-2 \mathrm{~cm}$ thick laminated clayey silt, (2) $1-2 \mathrm{~cm}$ thick laminated clayey silt, (3) laminated silty clay and clayey silt, (4) laminated silt and clay. 
Table 4

Radiocarbon dates from Lama Lake cores

\begin{tabular}{|c|c|c|c|c|c|c|}
\hline $\mathrm{NN}$ & Core & Depth $(\mathrm{cm})$ & Dated material & ${ }^{14} \mathrm{C}$ age & $\delta^{13} \mathrm{C}$ & Lab no \\
\hline 1 & $1111-5$ & $77-113$ & Non-identified macrofossils & $7480 \pm 420$ & -27.6 & AA39481 \\
\hline 2 & $1111-5$ & $119-163$ & Non-identified macrofossils & $4430 \pm 96$ & -27.4 & AA39482 \\
\hline 3 & $1111-5$ & 170 & Chemically enriched pollen fraction & $12,170 \pm 130$ & -23.3 & OxA-6067 \\
\hline 4 & $1111-5$ & $172-200$ & Non-identified macrofossils & $2126 \pm 72$ & -26.7 & AA39483 \\
\hline 5 & $1111-5$ & $202-235$ & Non-identified macrofossils & $5320 \pm 320$ & -28.3 & AA39480 \\
\hline 6 & $1111-5$ & $235-300$ & Non-identified macrofossils & $5319 \pm 92$ & -25.0 & AA39479 \\
\hline 7 & $1111-5$ & $305-307$ & Organic carbon & $10,590 \pm 130$ & -25.9 & OxA-5623 \\
\hline 8 & $1111-6$ & $302-348$ & Non-identified macrofossils & $5285 \pm 52$ & -28.2 & AA39478 \\
\hline 9 & $1111-6$ & $345-388$ & Non-identified macrofossils & $4100 \pm 200$ & -29.1 & AA39477 \\
\hline 10 & $1111-6$ & $377-379$ & Chemically enriched pollen fraction & $15,060 \pm 90$ & -23.6 & OxA-6066 \\
\hline 11 & $1111-6$ & $401-476$ & Non-identified macrofossils & $8190 \pm 170$ & -28.1 & AA39475 \\
\hline 12 & $1111-6$ & $477-520$ & Non-identified macrofossils & $8425 \pm 665$ & -28.2 & AA39474 \\
\hline 13 & $1111-6$ & $477-520$ & Non-identified macrofossils & $7980 \pm 450$ & -29.0 & AA39474 \\
\hline 14 & $1111-6$ & $477-520$ & Non-identified macrofossils & $10,830 \pm 530$ & -26.1 & AA39474 \\
\hline 15 & $1111-6$ & $520-523$ & Non-identified macrofossils & $9120 \pm 440$ & -24.4 & AA39473 \\
\hline 16 & $1111-6$ & $535-538$ & Non-identified macrofossils & $7950 \pm 90$ & -27.3 & AA39472 \\
\hline 17 & $1111-6$ & 540 & Chemically enriched pollen fraction & $14,760 \pm 120$ & -24.6 & OxA-6065 \\
\hline 18 & $1111-6$ & $552-554$ & Betula seed, Larix needles, insect remains & $9500 \pm 190$ & -28.0 & UTC8874 \\
\hline 19 & $1111-6$ & $552-554$ & Manually selected pollen & $700 \pm 400$ & -28.0 & UTC8875 \\
\hline 20 & $1111-6$ & $556-558$ & Daphnia remains & $9160 \pm 95$ & -27.4 & OS22695 \\
\hline 21 & $1111-7$ & $570-572$ & Non-identified macrofossils & $9260 \pm 190$ & -27.0 & AA39471 \\
\hline 22 & $1111-7$ & $580-582$ & Chemically enriched pollen fraction & $15,460 \pm 160$ & -23.4 & OxA-6064 \\
\hline 23 & $1111-7$ & $577-608$ & Non-identified macrofossils & $9520 \pm 140$ & -26.3 & AA39470 \\
\hline 24 & $1111-7$ & $603-605$ & Organic carbon & $15,680 \pm 180$ & -25.5 & OxA-5624 \\
\hline 25 & $1111-7$ & $611-648$ & Non-identified microfossils & $9970 \pm 120$ & -26.4 & AA39469 \\
\hline 26 & $1111-7$ & $649-653$ & Humic acids & $11,800 \pm 60$ & -25.9 & KIA3325 \\
\hline 27 & $1111-7$ & $653-696$ & Non-identified macrofossils & $11,470 \pm 180$ & -26.9 & AA39468 \\
\hline 28 & $1111-7$ & $699-736$ & Non-identified macrofossils & $11,390 \pm 320$ & -24.9 & AA39467 \\
\hline 29 & $1111-7$ & $736-792$ & Non-identified macrofossils & $6510 \pm 480$ & -24.7 & AA39466 \\
\hline 30 & $1111-7$ & $789-849$ & Non-identified macrofossils & $11,100 \pm 610$ & -27.5 & AA39465 \\
\hline 31 & $1118-1$ & $2-4$ & Humic acids & $2110 \pm 30$ & -27.0 & KIA3324 \\
\hline 32 & $1319-1$ & 30 & Wood remains & $500 \pm 35$ & -27.1 & UtC7419 \\
\hline 33 & $1341-4$ & 211 & Wood remains & $5255 \pm 48$ & -27.9 & UTC8876 \\
\hline 34 & $1341-4$ & 253 & Wood remains & $6200 \pm 60$ & -28.3 & UTC8877 \\
\hline
\end{tabular}

sedimentation rates could be significantly higher than during the Holocene. Thus, a younger age for the bottom sediment is also possible. Due to the poor chronological control for the whole PG1111 sequence we only use uncalibrated ages.

\subsection{Peat section}

The lower $175-20 \mathrm{~cm}$ is well-decomposed peat while the upper $20 \mathrm{~cm}$ is predominantly slightly or nondecomposed sedge peat (Fig. 4). The pollen diagram of the section is zoned by visual inspection (Fig. 4). PZ-I $(170-50 \mathrm{~cm})$ is notable for low pollen concentration. The pollen spectra are dominated by pollen of Picea obovata and Cyperaceae. PZ-II $(20-0 \mathrm{~cm})$ is notable for an increase in Betula sect. Albae and sect. Nanae pollen contents, while Larix and Picea obovata significantly decreased. All ${ }^{14} \mathrm{C}$ dates (Table 6) from the sequence are in good agreement, reflecting continuous peat accumulation at the site between ca. 6000 and $2500{ }^{14} \mathrm{C}$ yr BP.

\section{Paleoenvironmental reconstructions}

\subsection{Qualitative reconstruction}

We assume that the Lama record may represent a continuous sequence from ca. $18,000-16,000{ }^{14} \mathrm{C}$ yr BP, according to the age model. The spectra in PZ-I have very low pollen concentration and there are large amounts of reworked pre-Quaternary palynomorphs. The pollen zone is almost fit to olive-brown silty-clayey unit with very low organic content distinguished by Harwart et al. (1999). Identical pollen spectra were obtained from the lowest, not yet dated part of PG1341 core, taken from shallow water close to the western shore of the Lama Lake. The pollen data suggest that scarce steppe-like plant communities with Artemisia, Poaceae, Asteraceae, Caryophyllaceae, and Thalictrum dominated the vegetation around the lake. Tundra-like communities with Betula nana, arctic Salix, Dryas, Saxifraga, Oxyria, Carex and some Brassicaceae (such as Draba) might have grown in more mesic sites. Rare 
Table 5

Correlated pollen stratigraphy based on the relatively well-dated pollen records from the Taymyr Peninsula

\begin{tabular}{lll}
\hline${ }^{14} \mathrm{C}$ yr BP & Pollen stratigraphy & Reflected vegetation changes \\
\hline 0 & Modern pollen spectra & Modern vegetation cover \\
& & \\
ca 2500 & $\begin{array}{l}\text { Arboreal pollen contents became } \\
\text { similar to modern }\end{array}$ & $\begin{array}{l}\text { Vegetation cover approximated } \\
\text { modern conditions }\end{array}$
\end{tabular}

ca $4500 \quad$ Beginning of dramatical decrease in arboreal pollen content

ca 8500

ca 9000

ca 11,000

ca 12,000

Dramatic decrease of herb pollen content

Decrease of shrub pollen content

Maximal tree pollen content in the records

Graduate increase of tree pollen content in spectra
Small increase of shrub (mostly Betula nana) pollen content content and increase in shrub pollen

Shrub tundra or forest tundra (Betula nana and Alnus fruticosa) vegetation

Increase of Poaceae-Artemisia communities in vegetation

More shrub communities in local vegetation cover
Source

Nikol'skaya (1980, 1982), Kul'tina et al. (1974), Belorusova et al. (1987), Clayden et al. (1997), Andreev and Klimanov (2000), Andreev et al. (2002), Andreev et al. (this study) Nikol'skaya (1980, 1982), Kul'tina et al. (1974), Clayden et al. (1997), Velichko et al. (1997), Andreev and Klimanov (2000), Andreev et al. (2002)

Nikol'skaya (1980, 1982), Kul'tina et al. (1974), Belorusova et al. (1987), Clayden et al. (1997), Andreev and Klimanov (2000), Andreev et al. (2002), Andreev et al. (this study) Levkovskaya et al. (1970),

Nikol'skaya (1980, 1982), Clayden et al. (1997), Andreev et al. (2002), Andreev et al. (this study) Levkovskaya et al. (1970), Nikol'skaya (1980, 1982), Clayden et al. (1997), Velichko et al (1997), Andreev and Klimanov (2000), Andreev et al. (2002)

Nikol'skaya (1980, 1982), Velichko et al. (1997), Andreev and Klimanov (2000), Andreev et al. (2002), Andreev et al. (this study)

Nikol'skaya (1980, 1982), Velichko et al. (1997), Andreev and Klimanov (2000), Andreev et al. (2002), Andreev et al. (this study)

Andreev et al. (2002), Andreev et al. (this study)

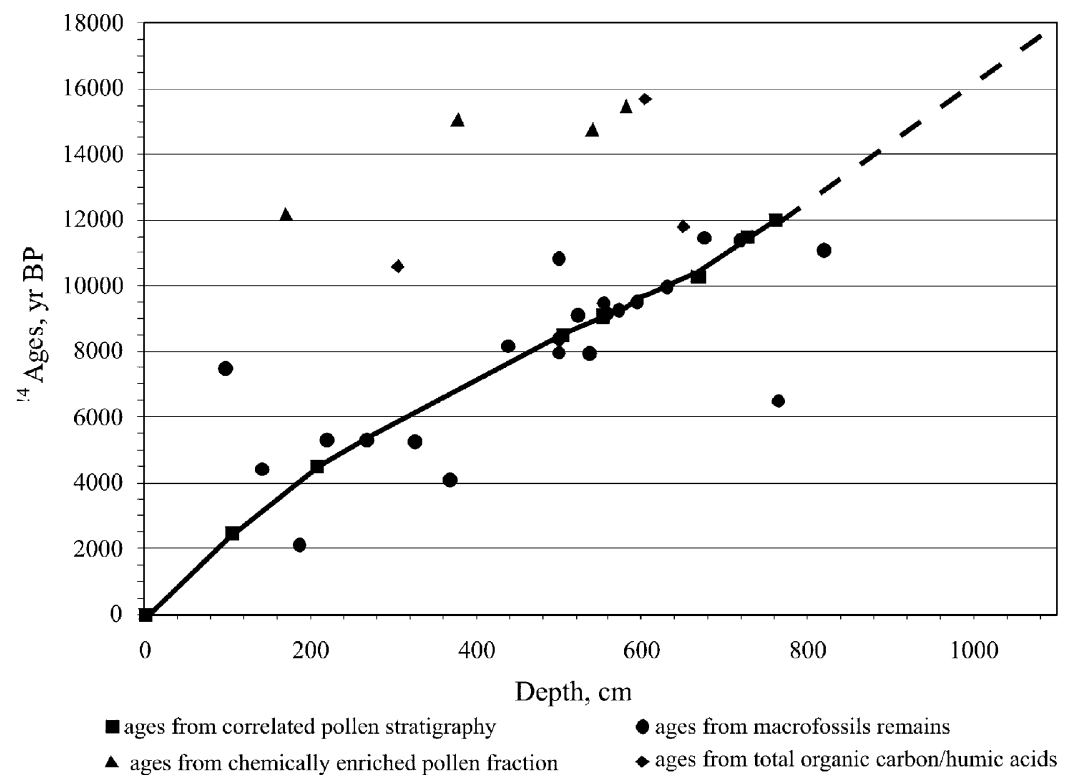

Fig. 3. Age/depth model. 


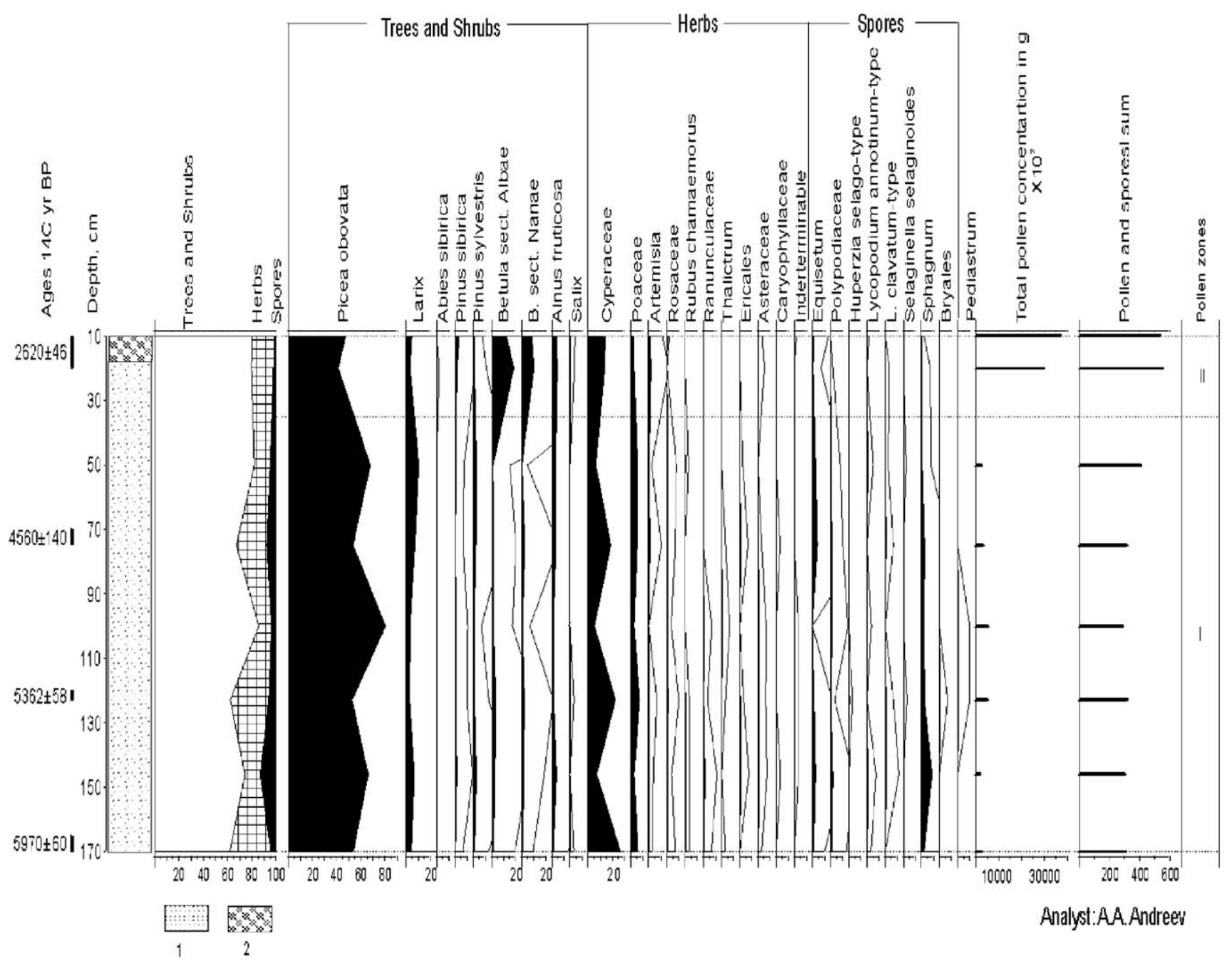

Fig. 4. Percentage pollen and spore diagram of the peat profile. (1) well-decomposed peat, (2) sedge peat.

Table 6

Radiocarbon dates from the peat profile in the Lama Lake catchment (for location see Fig. 1)

\begin{tabular}{lllll}
\hline Depth $(\mathrm{cm})$ & Dated material & ${ }^{14} \mathrm{C}$ age & $\delta^{13} \mathrm{C}$ & Lab no \\
\hline 20 & Carex seeds & $2620 \pm 46$ & -26.9 & AA39464 \\
75 & peat & $4560 \pm 140$ & -27.4 & AWI-220 \\
$120-123$ & Carex seeds & $5362 \pm 58$ & -26.1 & AA39463 \\
170 & peat & $5970 \pm 60$ & -28.9 & AWI-225 \\
\hline
\end{tabular}

pollen of trees and other shrubs are most likely reworked from older sediments.

Our pollen spectra are very similar to pollen spectra from the laminated lacustrine clayey-silt/silty-clay deposits, ${ }^{14} \mathrm{C}$ dated to $19,900 \pm 500 \mathrm{yr}$ BP (Kind, 1974) from the $60 \mathrm{~m}$ terrace near Norilsk (Ayakli-Melkoe site, $69.25^{\circ} \mathrm{N}, 89.00^{\circ} \mathrm{E}$ ). These spectra are also characterized by low pollen content, very low amount of arboreal pollen, and a dominance of Artemisia pollen between the non-arboreal pollen (up to $30-50 \%$ ), reflecting the similar steppe-like environment.

The slight increase of Betula sect. Nanae and a small peak of $B$. sect. Albae pollen contents at the upper part of the PZ-I may reflect Bølling warming, while a subsequent decrease of Betula pollen and a slight increase of Artemisia and Poaceae pollen contents in the upper layers may reflect Middle Dryas cooling.

The distinct increase of Betula sect. Nanae and Salix and the significant decrease of Artemisia, Poaceae and other herb pollen taxa contents in the PZ-II reflect a clear warming signal. According to the age model this warming correlates with the Allerød. A subsequent decrease in Betula pollen percentages and an increase of herb pollen taxa (mostly Cyperaceae) amounts in PZ-III probably reflect the Younger Dryas cooling.

The Late Glacial/Preboreal transition is characterized by a significant increase in Betula sect. Nanae and Salix pollen, Polypodiaceae, Sphagnum, Equisetum spores and a significant decrease in herbs pollen contents. 
According to the age model, this transition occurred ca $10,300-10,000{ }^{14} \mathrm{C}$ yr BP as seen everywhere in northern Eurasia (e.g. Khotinskiy, 1984; Velichko et al., 1997). A high content of Betula sect. Nanae and Salix pollen in the early Preboreal ${ }^{1}$ sediments (PZ-IV) suggest a broad distribution of dwarf birch and shrub willow associations (probably similar to those of modern shrub tundra) ca $10,000-9500{ }^{14} \mathrm{C}$ yr BP, but a relatively high content of non-arboreal pollen reflects the broad distribution of herbaceous vegetation. Numerous spores of Equisetum, Sphagnum and Polypodiaceae indicate wet habitats around the lake.

High Larix pollen content within the PZ-IV, dated to ca $9700-9600{ }^{14} \mathrm{C}$ yr PB indicates that larch forest has been already established near Lama Lake at that time. Such peaks, dated around $9600-9200{ }^{14} \mathrm{C}$ yr BP, are also characteristic for pollen and plant macrofossil records from West Siberia (Peteet et al., 1998), southwestern Taymyr (Levkovskaya et al., 1970; Clayden et al., 1997) and eastern Taymyr (Andreev et al, 2002). Larix forest dominated the vegetation $9600-9200{ }^{14} \mathrm{C}$ yr ago, after $9500 \mathrm{yr}$ BP with Alnus fruticosa as co-dominant.

A dramatic increase of Alnus fruticosa pollen content with some increase of Betula sect. Nanae, Picea obovata, and Lycopodium is also noticeable for the upper part of PZ-IV, ${ }^{14} \mathrm{C}$ dated ca 9200 yr BP. Such pollen spectra are very similar to recent ones near the northern limit of the modern taiga along the Yenisei River valley (Clayden et al., 1996) and probably reflect a similar vegetation of larch-spruce taiga with shrub alder and dwarf birch.

The Picea obovata pollen content and the total pollen concentration increase dramatically at ca $9100-8000{ }^{14} \mathrm{C}$ yr BP in PZ-V, suggesting dense spruce-larch forest with shrub alder and some tree birch dominated the vegetation around the lake. Other environmental records from Western Taymyr (e.g. Levkovskaya et al., 1970; Koshkarova, 1995) confirm the broad distribution of spruce during the Boreal. Koshkarova (1995), who has studied macrofossils from peat sequences near the Lama Lake, also concluded that spruce-larch forests covered the area. The expansion of spruce during the Boreal period reflects significant amelioration of the climate.

The content of Picea obovata pollen is the highest in the PZ-VI, indicating the broad distribution of spruce and warm climate conditions. The lower boundary of the zone coincides with a change in sedimentation, also suggesting a significant environmental shift (Harwart et al., 1999). According to the age model, the interval corresponds to the Atlantic period, ca. $8000-4500 \mathrm{yr} \mathrm{BP}$. ${ }^{14} \mathrm{C}$ dates from the PG1341 core (Table 4) and other

\footnotetext{
${ }^{1}$ We use the terms Preboreal, Boreal according to the modified chronological subdivision of Holocene (Khotinskiy, 1984). This subdivision is accepted in Russian scientific literature and has been used in all publications referred in this paper.
}

records from the area (e.g. Clayden et al., 1997; Andreev and Klimanov, 2000; Andreev et al., 2002) confirm such interpretation.

The pollen record from the nearby situated peat profile (Fig. 4) shows high content of Picea pollen, suggesting that spruce dominated on the peat bog at least $6000-4500{ }^{14} \mathrm{C} \mathrm{yr}$ BP. The lower percentages of Picea and higher percentages of Betula and Alnus in the lake sediments (PZ-VI of the Fig. 2) comparing with the peat record should be noted. This likely reflects differences between the local peat bog vegetation and more regional vegetation recorded in the lacustrine core. Dwarf shrub coenoses were probably common at higher elevations, contributing high contents of Betula sect. Nanae and Alnus fruticosa pollen to the lake sediment. The high percentages of the Lycopodium and the appearance of Selaginella selaginoides spores are notable within the PZ-VI. Both species are typical for boreal zone in Eurasia. Thus, spruce-larch forest with shrub alder and some tree birch dominated the vegetation around Lama Lake ca. $8000-4500{ }^{14} \mathrm{C}$ yr BP. Koshkarova (1995) also reconstructed spruce-larch forest vegetation in the Lame Lake region on the basis of macrofossil remains for this time interval.

A gradual decrease of Picea obovata pollen content, while Larix, Salix, Pinus, Cyperaceae, Lycopodium, Selaginella selaginoides, and Sphagnum contents increase in the PZ-VII, reflect a gradual deterioration of climate. Similar changes also occur in the peat accumulated after ca. $3500{ }^{14} \mathrm{C}$ yr BP (Fig. 4). High Picea pollen content in the peat is probably reflecting dense spruce forest near the peat land. We assume that the PZ-VII interval corresponds to the Subboreal period, ca. $4500-2500{ }^{14} \mathrm{C}$ yr BP according to the age model. Spruce gradually disappeared from the vegetation during that time. Koshkarova (1995) have also noted a gradual disappearance of the taiga species after $4500{ }^{14} \mathrm{C}$ yr BP. She noticed that the content of plant macrofossils from a peat profile near Lama Lake, ${ }^{14} \mathrm{C}$ dated to $2810 \pm 40 \mathrm{yr}$ $\mathrm{BP}$ is very similar to that seen today. In our peat profile accumulation ended ca. $2600 \mathrm{yr}{ }^{14} \mathrm{C}$ BP, probably reflecting local hydrological changes. Generally, vegetation cover became similar to modern larch-spruce forest type at ca. $2500{ }^{14} \mathrm{C}$ yr BP.

We assume that the upper $100 \mathrm{~cm}$ of the core (PZVIII) were deposited during the Subatlantic period since ca. $2500{ }^{14} \mathrm{C}$ yr BP. During this period Pinus pollen contents (long-distance wind-transported pollen) increased, while the content of local pollen decreased during the last 2500 years probably reflecting gradual climate deterioration. The increase of non-arboreal taxa may also reflect a deterioration of climate. Koshkarova (1995) also noticed that in the area "sparse larch forest gave way to open larch parkland". As today, larch forest with spruce and some tree birches dominated the vegetation. 
The significant increase of Betula sect. Albae pollen percentages in the upper part of the PZ-VIII, while Larix and Picea obovata decrease, mirrors the increasing role of birches in the local larch-spruce forests. The sharp decrease of total arboreal pollen contents and the increase of Artemisia pollen contents at $30-15 \mathrm{~cm}$ depth may be correlated with the so-called Little Ice Age (the ${ }^{210} \mathrm{~Pb}$ age model (Hagedorn et al., 1999) is in a good agreement with this interpretation). Spruce probably played a minimal role in the local vegetation at that time. Later, vegetation again became very similar to that of today.

\subsection{Biome reconstruction}

Biome reconstruction suggests three distinguishable vegetation phases (Fig. 5). The scores of steppe and tundra biomes are highest between ca 18,000 and 12,300 ${ }^{14} \mathrm{C}$ yr BP. These two vegetation types have very similar bioclimatic requirements and can grow under relatively cold and dry climate. Kaplan (2001) in his BIOME4 model distinguished five tundra biomes: cushion forb, lichen and moss tundra; prostrate dwarf-shrub tundra; erect dwarf-shrub tundra; low- and high-shrub tundra; graminoid and forb tundra. Taking into consideration that pollen taxa are often recognized at genera or family level, an objective attribution of pollen spectra to one of these tundra types would be rather speculative. However, at the qualitative level, spectra from the PZ-1 of the PG1111 core can be attributed to graminoid and forb tundra, or to dwarf-shrub tundra, or a combination of the two. Kaplan (2001) suggests that the distinctive bioclimatic limit to separate these biomes is a snow thickness of $15 \mathrm{~cm}$. If we apply such model scenario for the late Pleistocene part of the PG1111 pollen record, then low snow thickness and low soil moisture would allow cold grasses and forbs to dominate instead of cold dwarf shrubs, even without changes in temperature. Thus, we can only suggest that climate was drier than at present, especially during winters. This interpretation is in a good agreement with the climate reconstruction from the nearby-situated Ayakli-Melkoe site (Tarasov et al., 1999b).

Climate in Siberia during the LGM was drier than at present due to presence of ice sheets and low sea level (Kind, 1974; Velichko et al., 1984, 1997; Frenzel et al., 1992). It would also imply very low winter $P$ and very thin snow cover, explaining how large populations of grazing mammals could find food during the winters. In contrast to our interpretation and the reconstruction by Tarasov et al. (1999a), dryness in these studies has been associated with cold summers (e.g. Frenzel et al. (1992) assumed that $T_{\mathrm{VII}}$ in Central Siberia was $6-8^{\circ} \mathrm{C}$ colder than at present). However, Kienast et al. (2001), based on a precise macrofossil identification, suggests a diverse tundra-steppe vegetation at $18,000{ }^{14} \mathrm{C}$ yr BP near the

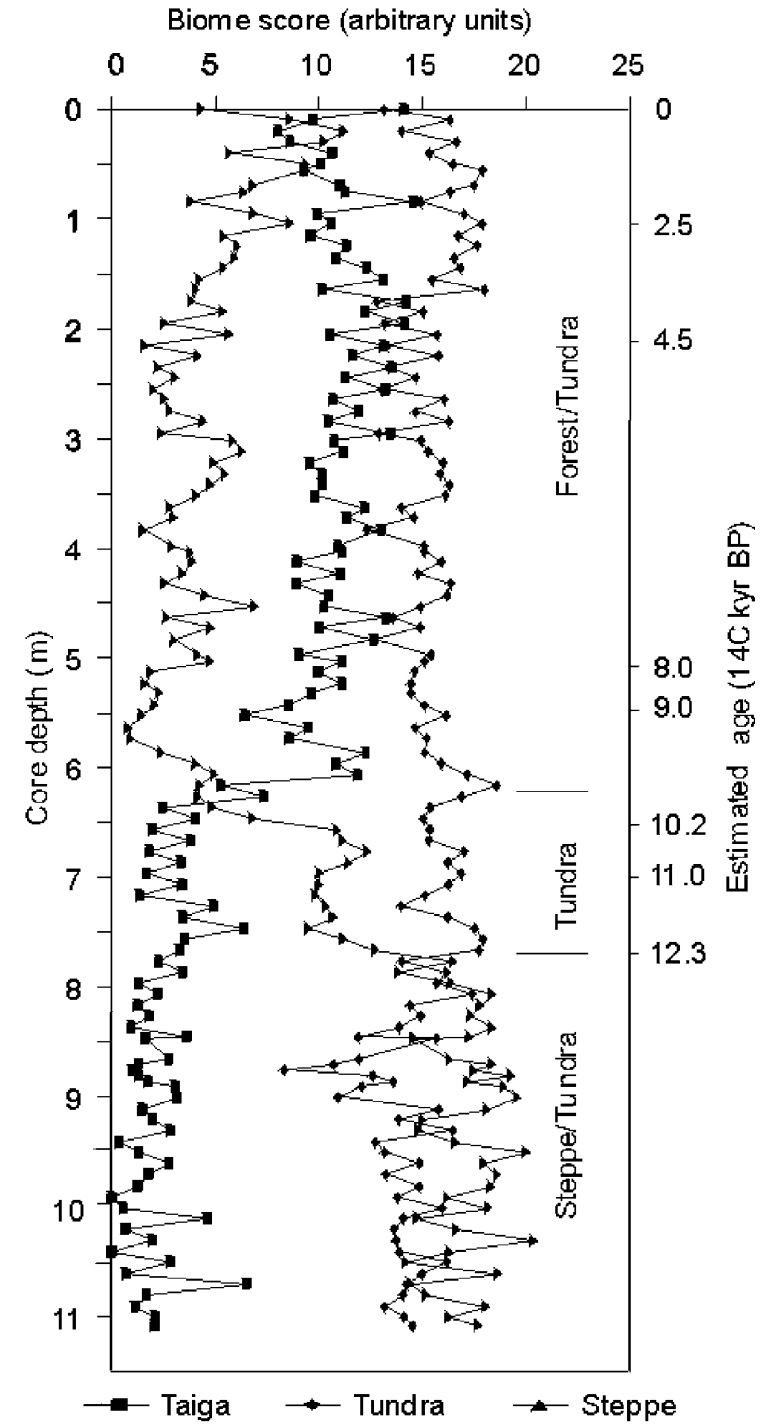

Fig. 5. Numerical scores of dominant vegetation types (biomes) reconstructed from the Lama Lake pollen record.

Taymyr Lake, implying that the LGM climate there was very dry with only thin snow cover, while the growing season $T$ were not lower than today.

Steppe biome scores decrease at the Late Glacial/ Early Holocene transition, while tundra biome scores increase (Fig. 5). The biome reconstruction suggests the spreading of shrub tundra associations ca $12,300-10,000$ ${ }^{14} \mathrm{C}$ yr BP. Such changes in the pollen spectra indicate an increase in snow thickness and soil moisture. Global warming and the associated retreat of the ice sheets and rise in sea level imply a weaker anticyclone regime in Siberia during the winter, leading to higher snow accumulation and vegetation changes. The scores of taiga are very close to the scores of tundra since ca $10,000{ }^{14} \mathrm{C}$ yr BP, suggesting that these biomes have codominated in the region since early Holocene. Cold evergreen and deciduous conifer forest (taiga) requires a climate wetter than graminoid and forb tundra, and 
warmer than dwarf-shrub tundra. The Lama Lake pollen record suggests that the $8000-4000{ }^{14} \mathrm{C}$ yr BP interval was an optimum for tree growth in the region.

\subsection{Quantitative climate reconstructions}

The extremely low pollen concentration, the low number of counted pollen, the presence of re-deposited pollen, and, the lack of arboreal pollen taxa limit the use of the pollen spectra below $760 \mathrm{~cm}$ of the core for quantitative climate reconstructions. The results of the Late Glacial and Holocene climate reconstruction obtained from the upper part of the core (above $760 \mathrm{~cm}$ ) are plotted in Figs. 6 and 7.

Both methods suggest that the $T_{\mathrm{VII}}$ reconstructed from the uppermost spectrum of the core are $1-1.5^{\circ} \mathrm{C}$ warmer than the regional $T_{\mathrm{VII}}$ in the Klimaticheskiy Atlas SSSR (1960) and Atlas Arktiki (1985). The $T$ anomalies reconstructed by both methods show similar trends. $T_{\mathrm{VII}}$ were slightly warmer than today during the Allerød, ca. $12,300{ }^{14} \mathrm{C}$ yr BP and were $2-3^{\circ} \mathrm{C}$ colder than today during the Younger Dryas, ca. $11,500{ }^{14} \mathrm{C}$ yr BP. During the early Preboreal, ca. $10,000{ }^{14} \mathrm{C}$ yr BP, $T_{\mathrm{VII}}$ became $0.5-1.5^{\circ} \mathrm{C}$ warmer than present. A short decrease in $T_{\mathrm{VII}}$ to the modern value is suggested for the mid-Preboreal, ca. $9600{ }^{14} \mathrm{C}$ yr BP. A slight $T_{\mathrm{VII}}$ fall is also occurred ca. $9000{ }^{14} \mathrm{C}$ yr BP. Later, at the end of the Boreal and during the Atlantic, the $T_{\mathrm{VII}}$ were $1.5-3.5^{\circ} \mathrm{C}$

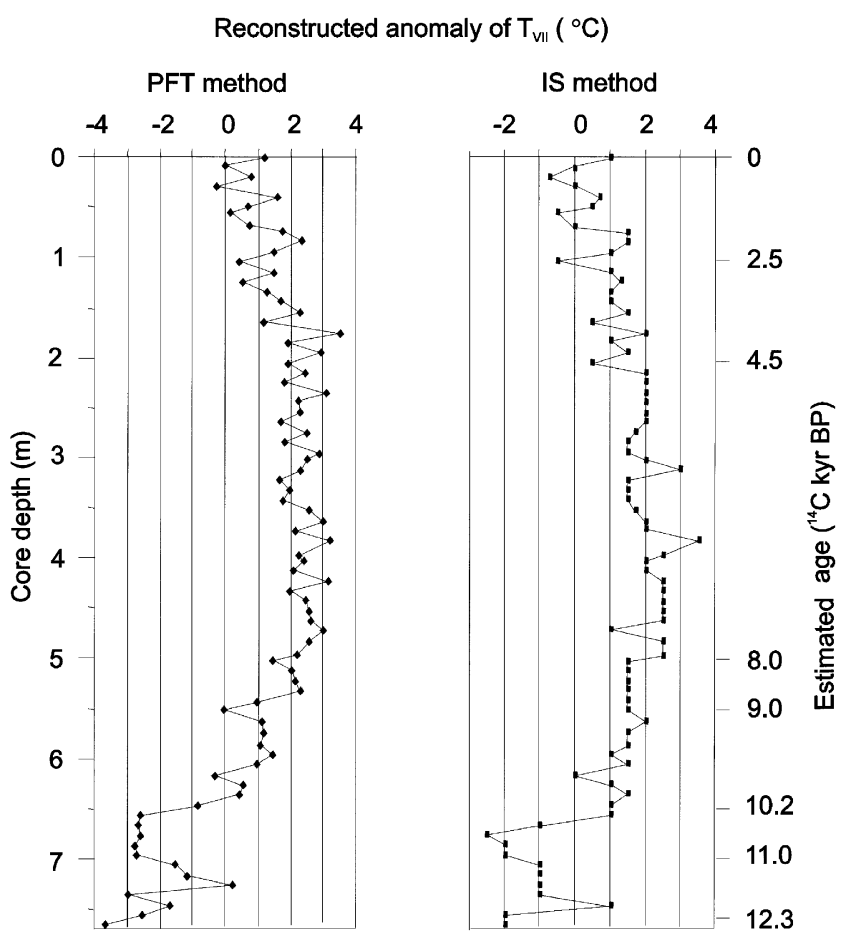

Fig. 6. Late Glacial and Holocene mean July temperature anomalies reconstructed from the Lama Lake pollen record by the IS (Klimanov, 1984) and the PFT (Tarasov et al., 1999a) methods.

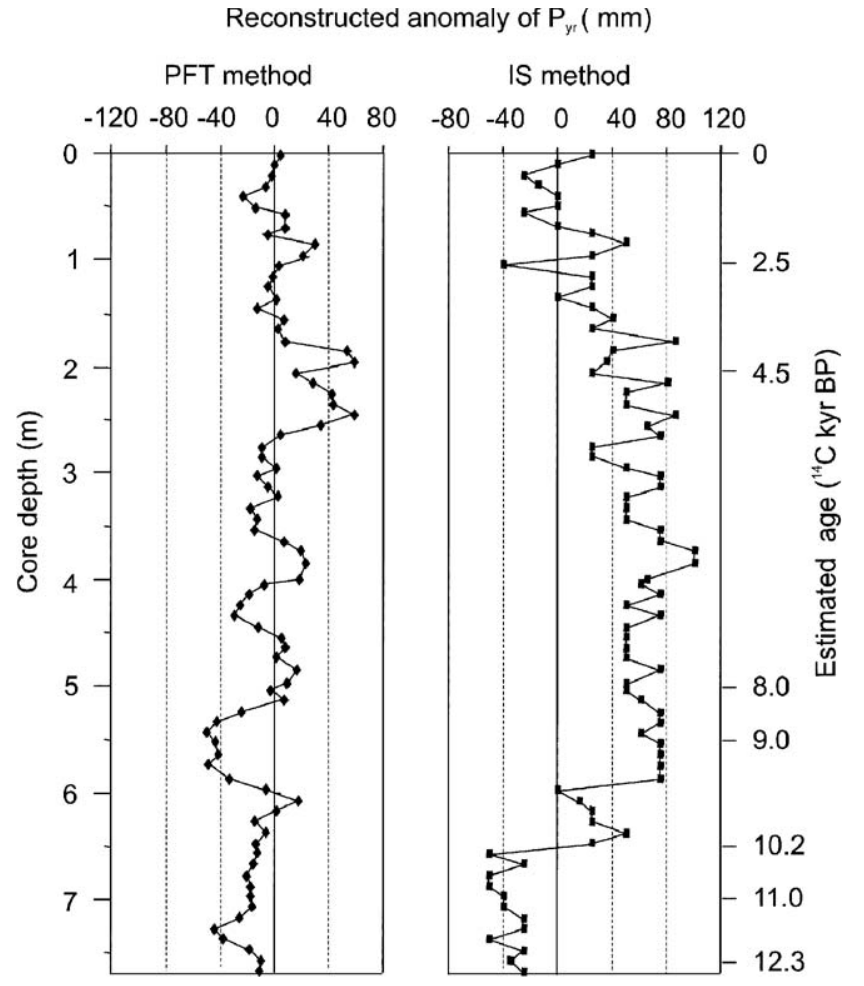

Fig. 7. Late Glacial and Holocene mean annual precipitation anomalies reconstructed from Lama Lake pollen record by the IS (Klimanov, 1984) and the PFT (Tarasov et al., 1999a) methods.

above modern values. The time of maximum warmth likely took place during the Atlantic period, ca. 8000 $4500{ }^{14} \mathrm{C}$ yr BP. The Subboreal (ca. $4500-2500{ }^{14} \mathrm{C}$ yr BP) $T_{\mathrm{VII}}$ were $0.5-2.5^{\circ} \mathrm{C}$ higher than present. During the Subatlantic period since $2500{ }^{14} \mathrm{C}$ yr BP $T_{\mathrm{VII}}$ anomalies fluctuated between -0.5 and $1.5^{\circ} \mathrm{C}$. The differences between the $T_{\mathrm{VII}}$ curves (Fig. 6) are rather in the amplitude of the changes than in the trends. Generally, these differences do not exceed $0.5-1{ }^{\circ} \mathrm{C}$, being thus within the possible error bars of the reconstructions (Klimanov, 1984; Tarasov et al., 1999a, b). Similar $T_{\mathrm{VII}}$ anomalies $\left(2^{\circ} \mathrm{C}\right.$ warmer than at present during the Boreal and Atlantic), based on macrofossils from peat profiles near Lama Lake, were obtained by Koshkarova (1995).

$P_{\mathrm{yr}}$ anomalies (Fig. 7) reconstructed with the IS and PFT methods are less coherent than the temperature curves, especially during the Late Glacial/Holocene transition. The PFT reconstructions suggest that $P_{\mathrm{yr}}$ anomalies slightly varied between -60 to $+60 \mathrm{~mm}$ from the Allerød to the present time. Two phases with relatively low $P_{\mathrm{yr}}$ occurred ca. $12,300-10,000{ }^{14} \mathrm{C}$ yr $\mathrm{BP}$ and ca. $9500-8500{ }^{14} \mathrm{C}$ yr BP; and several phases with $P_{\mathrm{yr}}$ higher than present are reconstructed at ca $10,000,8000,6000-5000,4500$, and slightly later than $2500{ }^{14} \mathrm{C}$ yr BP. The $P_{\mathrm{yr}}$ reconstructed by the IS method were ca $20-60 \mathrm{~mm}$ lower than present during the Late 
Glacial, became ca. $20-100 \mathrm{~mm}$ higher than present during the Atlantic period, and varied from -40 to $+40 \mathrm{~mm}$ during the last $3000 \mathrm{yr}$. Although the $P_{\mathrm{yr}}$ curves are not identical, the differences are too small to be interpreted and are within the error boundaries of the methods.

$P$ fluctuations reconstructed by Koshkarova (1995) show a larger range. During the Boreal period, $P$ was about $50 \mathrm{~mm}$ lower than today in the cold season, but about $80 \mathrm{~mm}$ higher in the warm season. $P$ was about 130 (cold season) and 180 (warm season) $\mathrm{mm}$ higher than today during the first half of the Atlantic period, ca. $8000-6000{ }^{14} \mathrm{C}$ yr BP. During the second half of the Atlantic period, ca. $6000-4500{ }^{14} \mathrm{C}$ yr BP, summer $P$ was about $50 \mathrm{~mm}$ lower than today, but winter $P$ was about $120 \mathrm{~mm}$ higher.

Such significant differences in the reconstructed $P$ may be connected with methodological differences as well as with the site of deposition (macrofossils from peat profiles rather reflect the local environment, while lacustrine records show a more regional signal).

\section{Conclusions}

Scarce steppe-like vegetation with Artemisia, Poaceae, and Cyperaceae dominated during the Late Glacial time, prior to ca. $12,000{ }^{14} \mathrm{C}$ yr BP. Tundra-like communities grew in more mesic sites. Climate fluctuations at the end of Late Pleistocene possibly correlate with the Bølling and Allerød warming and the Middle and Younger Dryas cooling.

Predominantly open herb communities have changed to shrub tundra ones at the Late Glacial/Holocene transition ca. $10,000{ }^{14} \mathrm{C}$ yr BP. Larch came to the area at ca. $9700-9600{ }^{14} \mathrm{C}$ yr BP, subsequently followed by Alnus fruticosa at ca. $9600{ }^{14} \mathrm{C}$ yr BP. Picea reached the area at ca $9200{ }^{14} \mathrm{C}$ yr BP. After $9000{ }^{14} \mathrm{C}$ yr BP spruce and larch forests with shrub alder and tree birch dominated the vegetation around the lake. The role of spruce in the forest gradually decreased after $4500{ }^{14} \mathrm{C}$ yr BP. Vegetation cover became similar to the modern one at ca. $2500{ }^{14} \mathrm{C}$ yr BP.

Biome reconstruction supports the qualitative interpretation of the pollen spectra. Three vegetation phases can be distinguished: high scores of steppe and tundra biomes prior to ca. $12,000{ }^{14} \mathrm{C}$ yr BP suggest a tundrasteppe vegetation; tundra biomes dominated during the Late Glacial/Early Holocene transition; similar scores of taiga and tundra biomes since ca. 10,000 yrs BP suggest that both types have co-dominated in the Holocene.

The climate reconstructions obtained with the IS and PFT methods show similar trends: $T_{\mathrm{VII}}$ were slightly warmer than today during the Allerød and $2-3^{\circ} \mathrm{C}$ colder during the Younger Dryas and became $0.5-1.5^{\circ} \mathrm{C}$ warmer than present again in the early Preboreal; two sharp decreases in $T_{\mathrm{VII}}$ to the modern value occurred at about 9600 and $8500 \mathrm{yr} \mathrm{BP}$; and after $T_{\mathrm{VII}}$ fluctuated between 1.5 and $3.5^{\circ} \mathrm{C}$ above modern values. $P_{\mathrm{yr}}$ anomalies are less coherent than temperature curves, especially during the Late Glacial-Holocene transition. However, the differences of the reconstructed $P_{\mathrm{yr}}$ values are rather small and stay within the error bars of the reconstructions.

\section{Acknowledgements}

This research was made possible through a project of the Helmholtz Association of National Research Centers (HGF) "Natural climate variations from 10,000 years to the present day". We thank Drs. A. Brauer, T. Kumke, S. Hicks, and D. Peteet for their critical commenting on the manuscripts and $\mathrm{C}$. Zich for the collecting material for AMS dating. We also specially thank Dr. R. Holme, who polished the English and made helpful comments.

\section{References}

Andreev, A.A., Klimanov, V.A., 2000. Quantitative Holocene climatic reconstruction from Arctic Russia. Journal of Paleolimnology 24 (1), 81-91.

Andreev, A.A., Siegert, C., Klimanov, V.A., Derevyagin, A.Yu., Shilova, G.N., Melles, M., 2002. Late Pleistocene and Holocene vegetation and climate changes in the Taymyr lowland, Northern Siberia reconstructed from pollen records. Quaternary Research 57, 138-150.

Atlas Arktiki, 1985. GUGK, Moscow. (in Russian).

Belorusova, Zh.M., Lovelius, N.V., Ukraintseva, V.V., 1987. Regional characteristics of the Holocene environmental changes on Taymyr Peninsula. Botanicheskiy Zhurnal 72 (5), 610-618 (in Russian).

Berglund, B.E., Ralska-Jasiewiczowa, M., 1986. Pollen analysis and pollen diagrams. In: Berglund, B.E. (Ed.), Handbook of Holocene Palaeoecology and Palaeohydrology. Interscience, New York, pp. $455-484$.

Clayden, S.L., Cwynar, L.C., MacDonald, G.M., 1996. Stomate and pollen content of lake surface sediments across the tree line on the Taymyr Peninsula, Siberia. Canadian Journal of Botany 74, 1008-1015.

Clayden, S.L., Cwynar, L.C., MacDonald, G.M., Velichko, A.A., 1997. Holocene pollen and stomate from a forest site on the Taymyr Peninsula, Siberia. Arctic and Alpine Research 29, 327-333.

Demidyuk, L.M., Kondrat'eva, K.A., 1989. Geochronological conditions of the Yenisei-Putoran region. In: Ershov, E.D. (Ed.), Geokriologiya SSSR. Tsentralnaya Sibir, Nedra, Moscow, pp. 164-183 (in Russian).

Faegri, K., Iversen, J., 1989. In: (Eds.), Textbook of Pollen Analysis, 4th Edition, revised by K. Faegri, P.E. Kaland, K. Krzyinski, Chichester, Wiley, 200pp.

Faustova, M.A., Velichko, A.A., 1992. Dynamics of the last glaciation in northern Eurasia. Sveriges Geologiska Undersökning, Seria Ca $81,113-118$.

Felzer, B.S., 2001. Climate impacts of an ice sheet in East Siberia during the Last Glacial Maximum. Quaternary Science Reviews 20 (1-3), 437-447. 
Frenzel, B., Pecsi, M., Velichko, A.A., 1992. Atlas of Paleoclimates and Paleoenvironments Reconstruction of Northern Hemisphere, Gustav Fischer Verlag, Stuttgart, 152pp.

Galaziy, G.I., Parmuzin, Y.P., 1981. Lakes of the North-Western Part of the Siberian Platform. Nauka, Novosibirsk, 190pp.(in Russian).

Grosswald, M.G., 1998. Late-Weichselian ice sheet in Arctic and Pacific Siberia. Quaternary International 45/46, 3-18.

Guiot, J., Goeury, C., 1996. PPPBASE, a software for statistical analysis of paleoecological and paleoclimatological data. Dendrochronologia 14, 295-300.

Hagedorn, B., Harwart, S., van der Loeff, M., Melles, M., 1999. Lead210 dating and heavy metal concentration in recent sediments of Lame Lake (Norilsk area, Siberia). In: Kassens, H., Bauch, H.A., Dmitrenko, I., Eicken, H., Hubberten, H.-W., Melles, M., Thiede, J., Timokhov, L. (Eds.), Land-Ocean System in the Siberian Arctic: Dynamics and History. Springer, Berlin, pp. 361-376.

Hahne, J., Melles, M., 1997. Late and post-glacial vegetation and climate history of the south-western Taymyr Peninsula, Central Siberia, as related by pollen analysis of a core from Lake Lama. Vegetation History and Archaeobotany 6, 1-8.

Hahne, J., Melles, M., 1999. Climate and vegetation history of the Taymyr Peninsula since Middle Weichselian time-palynological evidence from lake sediments. In: Kassens, H., Bauch, H.A., Dmitrenko, I., Eicken, H., Hubberten, H.-W., Melles, M., Thiede, J., Timokhov, L. (Eds.), Land-Ocean System in the Siberian Arctic: Dynamics and History. Springer, Berlin, pp. 477-499.

Harwart, S., Hagedorn, B., Melles, M., Wand, U., 1999. Lithological and biochemical properties in the sediments of Lama Lake as indicators of Late Pleistocene and Holocene ecosystem development of the southern Taymyr Peninsula, Central Siberia. Boreas $28,167-180$.

Isaeva, L.L., 1984. Late Pleistocene glaciation of north central Siberia. In: Velichko, A.A., Wright, H., Barnosky, K.W. (Eds.), Late Quaternary Environments of the Soviet Union. University of Minnesota, Minneapolis, pp. 21-30.

Joussaume, S., 1999. Modeling extreme climates of the past 20,000 years with general circulation models. In: Holland, W.R., Joussaume, S., David, F. (Eds.), Modeling the Earth's Climate and its Variability. Elsevier, Amsterdam, pp. 305-337.

Kaplan, J.O., 2001. Geophysical Applications of Vegetation Modeling. Ph.D. Thesis, Lund University, Lund, 113pp.

Khotinskiy, N.A., 1984. Holocene vegetation history. In: Velichko, A.A., Wright, H., Barnosky, K.W. (Eds.), Late Quaternary Environments of the Soviet Union. University of Minnesota, Minneapolis, pp. 179-200.

Kienast, F.W., Siegert, C., Dereviagin, A., Mai, D.-H., 2001. Climate implications of Late Quaternary plant macrofossil assemblages from the Taymyr Peninsula, Siberia. Global and Planetary Change 31, 265-281.

Kienel, U., 1999. Late Weichselian to Holocene diatom succession in a sediment core from Lama Lake, Siberia and presumed ecological implications. In: Kassens, H., Bauch, H.A., Dmitrenko, I., Eicken, H., Hubberten, H.-W., Melles, M., Thiede, J., Timokhov, L. (Eds.), Land-Ocean System in the Siberian Arctic: Dynamics and History. Springer, Berlin, pp. 377-405.

Kienel, U., Siegert, C., Hahne, J., 1999. Late Quaternary palaeoenvironmental reconstructions from a permafrost sequence (North Siberian Lowland, SE Taymyr Peninsula) - a multidisciplinary case study. Boreas 28, 181-193.

Kind, N.V., 1974. Geokhronologia Pozdnego Antropogena po Izotopnym Dannym (Geochronology of the Late Anthropogene by Isotope data). Nauka, Moscow, 200pp.(in Russian).

Klimanov, V.A., 1976. A technique of quantitative climate reconstruction for the past. Vestnik MGU, Seria Geograficheskaya 2, 92-98 (in Russian).
Klimanov, V.A., 1984. Paleoclimatic reconstruction based on the information statistical method. In: Velichko, A.A., Wright, H., Barnosky, K.W. (Eds.), Late Quaternary Environments of the Soviet Union. University of Minnesota, Minneapolis, pp. 297-303.

Klimaticheskiy atlas SSSR, 1960. Gidrometeoizdat, Moscow, 150pp. (in Russian).

Koshkarova, V.L., 1995. Vegetation response to global and regional environmental change on the Taymyr Peninsula during the Holocene. Polar Geography and Geology 19, 145-151.

Kul'tina, V.V., Lovelius, N.V., Kostyukevich, V.V., 1974. Palynological and geochronological studies of the Holocene sediments in the Novaya River basins on the Taymyr Peninsula. Botanicheskiy Zhurnal 59 (9), 264-270 (in Russian).

Kutzbach, J.E., Guetter, P.J, Behling, P.J, Selin, R., 1993. Simulated climatic changes: results of the COHMAP climate-model experiments. In: Wright, H.E., Kutzbach, J.E., Webb III, T., Ruddiman, W.F., Street-Perrott, F.A., Bartlein P, J. (Eds.), Global Climates since the Last Glacial Maximum. University of Minnesota Press, Minneapolis, pp. 24-93.

Leemans, R., Cramer, W., 1991. The IIASA data base for monthly values of temperature, precipitation and cloudiness of global terrestrial grid RR-91-18. International Institute for Applied Systems Analysis, Laxenburg.

Levkovskaya, G.M., Kind, N.V., Zavel'sky, F.S., Forova, V.C., 1970. Radiocarbon age of peatlands near Igarka and Holocene stratigraphy of West Siberia. Byulleten' kommisii po izucheniyu chetvertichnogo perioda 37, 94-101 (in Russian).

Melles, M., Wand, U., Hermichen, W.-D., Bergemann, B., Bolshiyanov, D.Yu., Khrutsky, S.F., 1994. The expedition Norilsk/Taymyr 1993 of the AWI research unit Potsdam. Berichte zur Polarforshung 148, 3-28.

Melles, M., Siegert, Ch., Hahne, J., Hubberten, H.-W., 1996. Klimaund Umweltgeschichte des nördlichen Mittelsibiriens im Spätquartärerste Ergebnisse. Geowissenschaften 14 (9), 376-380.

Möller, P., Bolshiyanov, D.Yu., Bergstein, H., 1999. Weichselian geology and paleoenvironmental history of the central Taymyr Peninsula, Siberia, indicating no glaciation during the last global glacial maximum. Boreas 28, 92-114.

Nikol'skaya, M.B., 1980. Paleobotanic characteristics of the upper pleistocene and holocene deposits on the Taymyr. In: Volkova, V.S. (Ed.), Paleopalinologia Sibiri. Nauka, Moscow, pp. 97-111 (in Russian).

Nikol'skaya, M.B., 1982. Paleobotanic and paleoclimatic reconstruction of the holocene in the Taymyr. In: Kind, N.V., Leonov, B.N. (Eds.), Antropogen Taymyra. Nauka, Moscow, pp. 148-157 (in Russian).

Nowaczyk, N.R., Harwart, S., Melles, M., 2000. A rock magnetic records from Lama Lake, Taymyr Peninsula, northern Central Siberia. Journal of Paleolimnology 23, 227-241.

Peteet, D., Andreev, A., Bardeen, W., Mistretta, F., 1998. Long-term Arctic peatland dynamics, vegetation and climate history of the Pur-Taz region, Western Siberia. Boreas 27, 115-126.

Peyron, O., Guiot, J., Cheddadi, R., Tarasov, P.E., Reille, M., de Bealieu, J.-L., Bottema, S., Andrieu, V., 1998. Climate reconstruction in Europe from pollen data, 18,000 years before present. Quaternary Research 49, 183-196.

Peyron, O., Jolly, D., Bonnefille, R., Vincens, A., Guiot, J., 2000. The climate of East Africa from pollen data, 6000 years ago. Quaternary Research 54 (1), 90-101.

Prentice, I.C., Cramer, W., Harrison, S.P., Leemans, R., Monserud, R.A., Solomon, A.M., 1992. A global biome model based on plant physiology and dominance, soil properties and climate. Journal of Biogeography 19, 117-134.

Prentice, I.C., Guiot, J., Huntley, B., Jolly, D., Cheddadi, R., 1996. Reconstructing biomes from palaeoecological data: a general 
method and its application to European pollen data at 0 and $6 \mathrm{ka}$. Climate Dynamics 12, 185-194.

Siegert, C., Derevyagin, A.Yu., Shilova, G.M., Hermichen, W.-D., Hiller, A., 1999. Paleoclimate indicators from permafrost sequences in the Eastern Taymyr lowland. In: Kassens, H., Bauch, H.A., Dmitrenko, I., Eicken, H., Hubberten, H.-W., Melles, M., Thiede, J., Timokhov, L. (Eds.), Land-Ocean System in the Siberian Arctic: Dynamics and History. Springer, Berlin, pp. 477-499.

Tarasov, P.E., Webb III, T., Andreev, A.A., Afanaseva, N.B., Berezina, N.A., Bezusko, L.G., Blyakharchuk, T.A., Bolikhovovskaya, N.S., Cheddadi, R., Chernova, G.M., Dorofeyuk, N.I., Dirksen, V.G., Elina, G.A., Filimonova, L.V., Glebov, F.Z., Guiot, J., Gunova, V.S., Harrison, S.P., Jolly, D., Khomutova, V.I., Kvavadze, E.V., Osipova, I.M., Panova, N.K., Prentice, C.I., Saarse, L., Sevastyanov, D.V., Volkova, V.S., Zernitskaya, V.P., 1998. Present-day reconstruction and mid-Holocene biomes reconstructed from pollen and plant macrofossil data from former Soviet Union and Mongolia. Journal of Biogeography 25, $1029-1053$.

Tarasov, P.E., Guiot, J., Cheddadi, R., Andreev, A.A., Bezusko, L.G., Blyakharchuk, T.A., Dorofeyuk, N.I., Volkova, V.S., Zernitskaya, V.P., 1999a. Climate in northern Eurasia 6000 ago reconstructed from pollen data. Earth and Planetary Science Letters 171, 635-645.

Tarasov, P.E., Peyron, O., Guiot, J., Brewer, S., Volkova V, S., Bezusko, L.G., Dorofeyuk, N.I., Kvavadze, E.V., Osipova, I.M., Panova, N.K., 1999b. Last Glacial Maximum climate of the former Soviet Union and Mongolia reconstructed from pollen and plant macrofossil data. Climate Dynamics 15, 227-240.

Tarasov, P.E., Volkova, V.S., Webb III, T., Guiot, J., Andreev, A.A., Bezusko, L.G., Bezusko, T.V., Bykova, G.V., Dorofeyuk, N.I., Kvavadze, E.V., Osipova, I.M., Panova, N.K., Sevastyanov, D.V., 2000. Last glacial maximum biomes reconstructed from pollen and plant macrofossil data from northern Eurasia. Journal of Biogeography 27 (3), 609-621.

Velichko, A.A., Isaeva, L.L., Makeyev, V.M., Matishov, G.G., Faustova, M.A., 1984. Late Pleistocene glaciation of the Arctic shelf and the reconstruction of Eurasian Ice sheets. In: Velichko, A.A., Wright, H., Barnosky, K.W. (Eds.), Late Quaternary Environments of the Soviet Union. University of Minnesota, Minneapolis, pp. 35-41.

Velichko, A.A., Andreev, A.A., Klimanov, V.A., 1997. The dynamics of climate and vegetation in the tundra and forest zone during the Late Glacial and Holocene. Quaternary International 41/42, 71-96. 